\title{
Bilgi Teknolojilerinin Yarattığı Örgütsel Değişim: Nasıl Bir İnsan Kaynakları Yönetimi?
}

Organisational Change Created by Information Technologies: The Type of Corresponding Human Resources Management

\section{Beyhan AKSOY*}

\begin{abstract}
Öz
Bilgi teknolojilerinin, bütünüyle bir örgütsel değişim yaratma rolü, önemli güncel konulardan biridir. Insan kaynakları yönetimi, seçme, yerleştirme, eğitim, performans değerlendirme ve ücretlendirme işlevleri açısından bu değişimden etkilenmiştir. Çalışma, söz konusu etkileri ele almaktadır. Daha sonra söz konusu etkiler, teknoloji-yoğun bir işletme üzerinde yapılan bir örnek olay incelemesi ile gözlenmiş ve işletmenin durumu değerlendirilmiştir.

Anahtar sözcükler: Bilgi teknolojileri, Örgütsel değişim, Insan kaynakları yönetimi.

Abstract

The role of information technologies with all its dimensions in creating an organizational change is an important contemporary topic. Human resources management in terms of recruitment, placement, training, performance evaluation and compensation has all been influenced by the organizational change being generated by the information technologies. The present paper discusses the mentioned effects. Afterwards, the effects were observed upon a case study provided by a technology-intense firm and cituation of this firm has been evaluated in this circumtances.
\end{abstract}

Keywords: Information technologies, Organizational change, Human resources management.

\footnotetext{
* Dr.; Başkent Üniversitesi Sağlık Bilimleri Fakültesi Sağlık Kurumları İşletmeciliği Bölümü Bağlıca Kampusu 06530 Ankara (beyhan@baskent.edu.tr). 
Bilgi Teknolojilerinin Yarattığı Örgütsel Değişimi Anlamak Neden Önemlidir?

Çağdaş yaşam, bireylerin çalışma hayatına bakışlarını da değiştirmiştir. Böylece insanlar, çalışma hayatında ve sonrasında güvence sağlayan, onlara gelişme imkanları tanıyan, mesleki birikimi destekleyen çalışma ortamları aramaya yönelmişlerdir. Bu yönelimin yanısıra, örgütler çevrelerinden bağımsız olmadıkları ve hem onu etkiledikleri hem de ondan etkilendikleri için (Scott, 1998) örgütlerdeki insan kaynakları yönetiminin temel anlayışı da değişmiştir. Böylece, insan kaynağı yeterliliği kavramı da, çalışanların fiziksel yeteneklerinin ve becerilerinin doğru zamanda, doğru yerde ve doğru biçimde konumlandırılması, geliştirilmesi ve sürdürülebilir olması biçiminde algılanmaya başlanmıştır.

Örgütün içerisinde bulunduğu çevresel etmenlerin en temel unsurlardan biri de teknoloji düzeyidir. Bu bağlamda teknoloji, yalnızca üretim tekniklerini değil, aynı zamanda bilgi teknolojilerini de kapsamaktadır. Bilgi teknolojileri (BT) ile insanın birbirlerine olan karşılıklı bağımlılığı (DeMarie ve Hitt, 2000) ve bu bakımdan bilgi teknolojilerinin firmaların örgütsel yaşamındaki tamamlayıcı işlevi (Autor, Levy ve Murnane, 2003) BT'ye insan kaynakları yönetimi çerçevesinden de bakma gereğini doğurmaktadır.

Örgütlerin yapı ve işleyişlerini daha iyi anlayabilmek için, onların içerisinde bulundukları çevresel değişimleri izlemek gerekir. Bu yüzden, çevresel unsurlardan biri olan BT'nin yarattığı değişimi anlamaya çalışmak, örgütleri anlayabilmek bakımından özel önem taşımaktadır.

Bu çalışmada BT'deki değişimler, insan kaynakları yönetimi politikaları çerçevesinde alınan kararlar ve bu bağlamda BT'nin insan kaynakları uygulama alanlarını etkileyişi ile sınırlandırılmış bir çerçeve içerisinde incelenecektir.

\section{Bilgi Teknolojilerinin Yarattığı Örgütsel Değişim}

Bilgi teknolojilerinin, örgütsel süreçlerdeki değişim üzerinde başlatıcı, kolaylaştırıcı ve imkân sağlayıcı etkileri vardır (Chan, 2000).

Bilgi teknolojileri öncelikle, iş dünyasına internet, e-posta, video konferans, intranet gibi araçlarla iletişimi kolaylaştırma ve çabuklaştırma avantajı sağlamaktadır. BT, kurum içi veya küresel anlamda bilgi gereksinimini böylece sağlarken, aynı zamanda "extranet" gibi araçlarla da örgütlerin karşılıklı bir ilişki içerisinde bulunduğu ağ ortamında bilgi alışverişi yapılmasını sağlamaktadır. Bu yollarla BT, firmaların işgücü, zaman ve işlem maliyetlerini azaltmaları bakımından yeni imkânlar doğurmuştur.

Diğer yandan, hem işletme hem de müşteri açısından çabukluk, seçenek 
çokluğu ve daha fazla ürüne erişebilme şansı tanımasından ötürü e-ticaret, örgütlerde önemli değişimler yapılmasını gündeme getirmiştir. Örgütsel karar almak boyutunda ise, BT, yönetim bilgi sistemleri aracılığıyla, gerekli olan verilerin toplanma, depolanma ve yöneticiler için anlamlı hale getirilmelerinin yanısıra, dışsal tehditlere de karşılık verebilmeye ve çeşitli fırsatları zamanında yakalamaya imkân sağlamıştır (Alkadi, Alkadi ve Totaro, 2003). Bu bakımdan BT yalnızca yöneticiler için değil, herkesin kullanabileceği kolaylıktaki yazılımların yaygınlaşmasına olanak sağlamaktadır. Bunun ötesinde BT işyerindeki otomasyonun etkisini artırarak iş süreçlerinde büyük değişimler oluşturmuş ve örneğin tehlikeli işlerin insan yerine makine ile gerçekleştirilmesini sağlamak gibi yaşamsal değişiklikler yaratmıştır.

BT veriyi işleyen, bilgiyi toplayan, elde edilen materyali depolayan, bilgiyi yayan ve iletişimi hızlandıran işlevleriyle, kullanıcılar, onların işleri ve iş çevreleri üzerinde önemli etkilere sahiptir. Önceki dönemlerde bilgi teknolojilerinin örgütün tüm stratejisinde yalnızca destekleyici bir rol oynadığı düşünülürken, artık açıkça farkına varılmaktadır ki BT, yeni ihtiyaçlar yaratma, yeni ürün geliştirmeye neden olma ve yeni süreçleri ortaya çıkarma gibi iş, işlem ve operasyon süreçlerinde de önemli roller oynamaktadır.

$O$ halde $B T$, bir süreçteki insan gücünün yerine geçebilir ya da ona yönelik ihtiyacı azaltabilir. BT ile karar verme sürecine özgü analiz olanakları geliştirilebilir, bir süreç içerisinde gruplar arasındaki bağlantıyı doğrudan kurarak aracıları devreden çıkarılabilir, bilgi edinimini coğrafi uzaklıkların etkisinden bağımsızlaştırılabilir, bilgi hızlı ve kolay aktarılabilir, koordine edilebilir, bilginin süreç geliştirmede kullanılması yaygınlaştırılabilir ve yapılandırılmış süreç faaliyetlerini rutin işler haline dönüştürülebilir (Chan, 2000). Ayrıca karmaşık süreçler içindeki ara aşamaları azaltılabilir ve böylece gerekli görevlerin daha bağımsız bir biçimde başarılmasında araç olarak kullanılabilir. Kısaca BT ile daha akılıca ve verimli çalışma imkânlarının oluşması sağlanabilir.

Diğer taraftan BT ile örgütsel öğrenme de kolaylaştırılır. Firmaların coğrafi olarak yayılmış birimlerinin ve aralarındaki operasyonların daha iyi koordine edilmesini sağlar (DeMarie ve Hitt, 2000). Bu durum, küçük işletmelerin, diğer işletmelerle kurabilecekleri bağlantı ve ortaklıkların kolaylaşması nedeniyle, büyük işletmelerle rekabet edebilmelerini kolaylaştırması açısından da önem taşımaktadır.

Insan sermayesi ile BT arasında karşılıklı bir bağımlıık vardır. BT, insan sermayesinin sürekli bir şekilde gelişimini sağlayabilir, bu bakımdan örgütlerde BT'den sürekli olarak yararlanılmalıdır. Böylece BT'den insan sermayesinin geliştiriminde yararlanma ölçüsünde BT, firma için dinamik bir örgütsel rekabet edebilirliğin anahtar unsuru haline gelecektir. 


\section{İnsan Kaynakları Yönetimi Politikalarını Etkileyen Değişimler}

Doğal olarak teknolojideki ilerlemeler, BT'nin kullanımını artırmıştır. Bu da yalnızca iş içeriklerinde değil, bütüncül bir örgütsel değişime yol açmış görünmektedir. Özellikle son 20 yıl içerisinde, BT'nin örgüt içerisindeki varlığı, örgütlerde bir çok değişimin yaşanmasına neden olmuştur. BT'nin işgücü nitelikleri boyutunda yaratmış olduğu, çalışma hayatını değiştirerek onu yeni örgütsel düzenlemelere maruz bırakan bu değişimlerden çalışmamızın kapsamı bağlamında değinilecek olanlar, aşağıda kısaca sunulmuştur.

\section{Ademi Merkeziyetçileşme}

Ademi merkeziyetçileşmede karar verme erki, daha hızı ve daha örgüt içi etkileşimci kararlar alabilen yöneticilere kaymıştır (Bengshir, 1996; Townsend ve Bennett, 2003; Miller ve Cardy, 2000). Bu da örgütlerdeki yönetici sayılarının nisbi olarak azalmasına yol açmıştır. Çünkü, merkezi karar verme otoritesi ile operasyonel birimler arasında bilgiyi ileten örgütsel ara tabakalara artık o kadar intiyaç duyulmamaya başlanmıştır. Dolayısıyla, bu tür yeni örgütsel yapılanmalarda bireyler veya grupların daha bağımsız karar verme yeteneklerine sahip olmaları ve öz yönetime yönelik becerilerinin daha da geliştirilmesi gereği ortaya çıkmaktadır. Bu durum elbette ki her şeyden önce, insan kaynakları yönetiminin personel sağlama-seçme ve eğitim programlarına yansıyacaktır.

\section{Yeni İsdihdam İlişkileri}

BT'nin isdihdamla ilintili olarak yarattığı en önemli değişikliklerden birisi, hiç kuşkusuz, yeni iş olanaklarının ortaya çıkmasıdır. BT'nin yayılımıyla birlikte her geçen gün, önceleri hiç sözü edilmeyen işler ve görevler için personel aranmakta, böylece hiç duyulmamış işler ve görevler iş yaşamında yerlerini almaktadırlar. O halde, BT yüzünden insanların yerine makinaların geçeceğini ve dolayısıyla kütlesel bir işsizliğe yol açacağını savunan görüş, BT vasıtasıyla yeni ve otomasyon ortamını değiştirmeksizin yaratılan iş ve mesleklerin oluşmasıyla da iyi bir yanıt almaktadır (Turban, McLean ve Wetherbe, 2002).

BT'nin yarattığı değişimlerden bir kısmı, dış kaynaklardan daha fazla yararlanma ve stratejik işbirliği yollarıly gerçekleşmektedir. Nitekim işletmeler, bordrolama, yazılım geliştirme, hasta veya müşteri takip formları hazırlama gibi birçok konuda, bu ihtiyaçlarının gerektirdiği teknolojiyi kendilerinin üretmesi yerine, artık yavaş yavaş onları dışarıdan sağlama yolunu tercih etmektedirler (Townsend ve Bennett, 2003).

BT'deki ilerlemeler sonucunda örgütler, önemli miktardaki bilginin iş süreçlerine aktarılması ve yönetilmesine dair gereken işgücünü daha çok 
dışarıdan sağladıkları için, örgüt içlerindeki işgücü profillerinin farklılaşmaya başladığı izlenmektedir. Bu durum ise, doğal olarak yeni isdihdam ilişkilerini gündeme getirmektedir. Örneğin, bahsedilen güncel iş ortamlarında kimin kim için çalıştığı yavaş yavaş belirsizleşmeye başlamıştır. Sözgelimi, hizmetin satın alındığı işletmenin sözleşmeli personelinin ofisi, hizmet verilen işletmenin içinde olabilmektedir ve pekala bu kişinin, oradaki personelle birlikte çalışması daha uygun görülebilmektedir.

\section{Ortak Çalışma Biçimlerinde Değişmeler}

BT iletişimi kolaylaştırmak yoluyla, çalışanların birlikte çalışma biçimlerini de değiştirmiş ve hatta onları daha da zenginleştirmiştir. Örneğin, masaüstü video konferans sistemleri, ses, video ve metin anlamında, e-posta veya telefonun getirdiği faydalardan çok daha fazlasını ve üstelik eş ve gerçek zamanlı olarak sağlayabilmektedir. Dolayısıyla BT, çalışanların kendi aralarındaki bilinen yüz yüze iletişimlerinin dinamiklerini değiştirmekte ve görüntü yoluyla iletişimin yeni etkiler yaratmasına imkân vermenin yanısıra, daha karmaşık araçların da bu işbirliğine dahil olmasını sağlamaktadır. Bu sistemler, aynı zamanda bilginin eş ve gerçek zamanlı bir biçimde görüntülenmesine, paylaşımına ve düzenlenmesine de izin vermektedir. Bu zengin yapı, fiziksel anlamda bir arada olmayan insanların dahi, etki ve etkileşim yaratan bir biçimde bir araya getirilmelerini sağlamaktadır (DeMarie ve Hitt, 2000).

Çalışanların bu şekilde bir araya gelmelerinin bir sonucu olarak, sanal (virtüel) takımlar (ekipler) oluşturulmaya başlanmıştır. Böylece, problem çözme veya projelere hizmet etme bakımından sanal takımlar, örgütlere mekândan bağımsız bir "potansiyel yetenek havuzu" sağlayabilmektedirler. Ayrıca bu durum, sanal takım üyelerini işlerinde daha fazla güdüleyebilmektedir.

Miller ve Cardy (2000), bu tür grupların arzulanan sonuçlara ulaşmaları halinde, çeşitli ödüllendirme mekanizmalarıyla desteklenmesi gerektiğini önermektedirler. Grup performansının, örneğin bir ücretlendirme mekanizmasıyla teşvik edilirse daha da artabileceği savunulmaktadır.

\section{Tele- iletişim ve Tele-iş}

Yukarıda değinilen işbirlikleri bağlamında örgütlerin sınırlarını belirsizleştirmede etkili olan bir başka faktör ise, tele-iletişimdir (DeMarie ve Hitt, 2000). Telefon, faks, e-posta, video konferans gibi BT araçlarının kullanımıyla sürdürülebilecek tele-iletişim, örneğin merkezle şubeler arasındaki günlük yolculukları önlemektedir. Böylece tele-iletişim, çalışanların zaman planlamasının daha esnek bir biçimde yapılabilmesine de olanak sağlamaktadır. 
Çalışanların işlerinin neredeyse tamamını tele-iletişim yoluyla gerçekleştirdikleri tele-işlere gelince, bu tür ve çoğunlukla yeni yeni geliştirilen işlerde maliyetler, fiziksel iş ortamı kavramının ortadan kalkış oranına bağlı olarak, iyice azalabilmektedir. Öte yandan, tele-iş yoluyla, yerine getirilmek istenilen görevlere ilişkin olarak kesilme, engellenme, bozulma gibi sebeplerin de önüne geçilebilir ki, bu, bir yerde böylece bağımsızlaşmış çalışma avantajının kullanılması demektir.

Buna karşın tele-iletişimde yoğunlaşma, aynı amaç için çalışan kişilerden alınabilecek sosyal desteğin azalması anlamına gelebilir; örneğin kişilerin iş yerlerinde karşılaştıkları sorunları ilk amirleriyle yüz yüze temas kurarak daha çabuk çözebilme avantajlarını ortadan kaldırabilir (Maruca, 1998). BT-yoğun örgütlerde özellikle tele-iletişimi kullananlar, kariyerlerine olumlu etki yapabilecek "işyerinde bulunma", "ara kademe yöneticisi olma" gibi etmenlerin etkisinden yeterince yararlanamayabilirler.

Bu tür çalışma ortamlarında, denetleme, yönlendirme ve çalışanları güdüleme gibi yaklaşımlar için uygun yollar aranmalıdır. Tele-iş ve teleiletişimin kişilerin sosyal ve yüz yüze etkileşimlerini zayıflatma olasıılığı, özel bir rehberlik hizmetiyle oldukça azaltılabilir (Miller ve Cardy, 2000).

Diğer taraftan, tele-işin yaygınlaşmasının getirdiği sonuçlardan biri de, proje bazlı (sözleşmeye dayalı olarak geçici statüde isdihdam edilen) ve dolayısıyla durumsal çalışan işgücünün daha fazla ortaya çıkmasıdır. Söz konusu BT-yoğun örgütlerin bu tür işgücü talep etmelerinin nedenlerinden biri, BT yoğun çalışma düzeninde yer alan bu çalışanların eğitim ve uyum intiyaçlarının, çoğunlukla BT araçlarını öğrenmeye yönelik olmasıdır (Hitt, Keats ve DeMarie, 1998). Başka bir biçimde ifade etmek gerekirse, daha uzun süren ve bu yüzden daha maliyetli olan "örgütsel gerekleri ve prosedürleri öğrenmek" gereği, durumsal çalışanlarda daha geri plana itilebilen bir intiyaç haline dönüşmektedir. Dolayısıyla, BT araçlarının en son kullanım ve işletimlerini öğrenerek bilgilerini güncel tutmak, ilgili durumsal çalışanlarda daha fazla önem kazanmaktadır.

Durumsal çalışanların tercih nedeni, örgüt dışındaki gelişmeleri daha fazla yakalamış bulunmaları olasılığından da kaynaklanabilir. Ancak, bu biçimdeki çalışmanın getirebileceği sakıncalar da açıktır. Durumsal çalışanları yukarıda sayılan nedenlerden ötürü kendilerini içinde bulundukları örgüte ait hissetmeyerek, o örgüte herhangi bir bağlılık duymayabilirler ve bu yüzden diğer iş gruplarılya bütünleşmeleri daha zor olabilir. $O$ halde firma yönetimi, durumsal çalışanların isdihdamında izlediği politikalara daha fazla dikkat sarfetmelidir.

Unutulmaması gereken bir konu da, tele-iletişim yoluyla sürdürülen uzaktan iş yapma eylemine sendikaların pek sıcak bakmayacağı olgusudur. Çünkü, açıkça anlaşılacağı üzere bu çalışma sistemi, çalışanları merkezi bir 
yere ve ortak bir çalışma programına bağlamadığı için, onların sendikalaşmasını zorlaştırmaktadır.

Son olarak, tüm çalışanlara nazaran büyük oranda durumsal çalışan kullanmanın insan kaynakları yönetimi açısından da çeşitli sakıncaları bulunduğu vurgulanmalıdır. Sözgelimi, durumsal çalışanlarla uygun bir yerde ortak bir eğitim programı sürdürebilmek, daha zordur.

\section{Eğitim ve Beceri Gereksinimleri}

BT, gün geçtikçe daha fazla eğitimli işgücü gerektiren değişimler yaratmaktadır. Bilgisayar temelli teknolojilerin ve üniversite mezunu işgücü ihtiyaçlarının artışı, "beceri yanlısı" ve hatta "beceri önyargılı" bir teknik değişim oluşumunun dolaylı kanıtıdır (Autor, Levy ve Murnane, 2003). Söz konusu beceri önyargısı, sürekli olarak daha yüksek becerili çalışanların tercih edilmelerine yönelik bir değişime yol açmaktadır (Bresnahan, Brynjolfsson ve Hitt, 2002).

BT'nin sonucu olan örgütsel değişimler, zamanla ilgili işgücü pazarında da bir bütüncül değişime yol açmaktadır. BT'nin gün geçtikçe ucuzlaması ve gelişmesi, işletmelerin daha fazla tamamlayıcı yatırım yapmalarına neden olmaktadır.

İş gücü profilinde meydana gelen bir diğer değişim ise BT'nin, programlanmış yöntemlerle rutin iş yapan çalışanların yerine geçmesiyle ortaya çıkmıştır (Bensghir, 1996). Böylece işletmeler, yüksek becerili çalışanlarını daha etkili bir şekilde kullanmaya başlamaktadırlar.

Öte yandan, düşük ücretle çalışan ve kısıtlı beceriye sahip örgüt çalışanları, daha önceleri bilgisayar kullanmaksızın yaptıkları işleri bilgisayarlı bir biçimde sürdürebilecekleri hizmet içi eğitimi alıp yeni tarzda çalışmaya başlayınca, aynı işleri yapmak için harcadıkları günlük zamanın kısaldığı gözlenmektedir. Ancak böylelikle işlerin azalmadığı, aksine zamanı dolduracak yeni görevler ve yeni işlerin ortaya çıktığı da izlenmektedir (Borghans ve Weel, 2004). Rutin görevleri yerine getiren çalışanlara duyulan intiyaçtaki azalma, bu personelin de rutin olmayan ve esneklik, yaratıcılık, problem çözme becerisi ve karmaşık ilişkiler gerektiren görevlere kaymalarını gerektirmiştir.

İşlevsel açıdan bilgisayarların, "yerine geçme" ve "tamamlayıcılık" gibi iki ayrı rolü beraberce üstlendiği düşünülebilir. $\mathrm{O}$ halde, BT rutin işlerde kişilerin yerine geçerken, rutin olmayan ve çoğunlukla daha karmaşık işlerde ise kişilerin görevlerini tamamlamaktadır. Tamamlayıcı türden işler, kolayca düşünülebileceği gibi daha eğitimli çalışanlara olan talebi artırmıştır (Entorf, 
Gollac ve Kramarz, 1999). Ayrıca, bilgisayarlaşma öncesinde rutin görevlerin işgücü girdisi göreceli olarak daha yoğun sektörler, (örneğin bankacılık sektörü), diğer sektörlere göre daha fazla bilgisayar sermayesine yatırım yapma zorunluluğu duymuşlardır. Tabii böylesine durum ve olgular da, rutin olmayan görevlere yönelik talebi artırmıştır (Autor, Levy ve Murnane, 2003).

\section{Aracıların Azalması}

İşgücü pazarı, BT'nin etkisiyle değiştikçe, özellikle işletmelerin işlerini yürütmede devreye giren dağıtımcılar, perakendeciler, komisyoncular, emlakçılar, seyahat acentaları gibi bazı aracı işletmelerin sayıca azalmaya başlandığı görülmektedir (Wimmer, Townsend ve Brian, 2000). Nasıl ki, yukarıda da ifade edildiği üzere, örgüt içinde var olan bilgiyi örgüt hiyerarşisi uyarınca yukarıdan aşağıya veya aşağıdan yukarıya iletmede rol üstlenen orta kademe yöneticiliği yavaş yavaş ortadan kaybolmağa başlamışsa, aynı olgu pazardaki aracı aktörler için de söz konusu olmaktadır. Bilgiye herkes daha kolay ulaşabilmeye başladığı için örgütler de, pazar ve örgüt arasındaki bilgi eksikliğinin gidericisi olan aracılara daha az ihtiyaç duymaktadırlar. Bu durum, aracı işletmeleri de değişmeye zorlamaktadır ve onlar da rollerini, BT'nin daha yoğun bir şekilde kullanıldığı biçimlerde devam ettirmeyi yeğlemektedirler. Örneğin, bu aracı işletmeler, internet üzerinden de hizmet vermeğe başlamışlardır.

İnsan kaynaklarının kullanımı yönünden söz konusu durumun yarattığı etki şu şekilde belirtilebilir: Aracı işletmelerde çalışanlara özgü bazı meslek gruplarına yönelik talebin azalması, makro ekonomik anlamda isdihdam yapısının değişmesine yol açmaktadır. Bu durumda, bilgiye erişme becerisini kazanma çabasına giren ve bunu başaran kişiler, örgütte daha fazla vazgeçilmez olacak ve bu özelliğe sahip kişilerin isdihdam edilme şansları daha yüksek olacaktır.

\section{Ev Örgütler}

Tele-iletişim ve tele-işin yaygınlaşmasıyla, sadece işletmelerin değil, iş ve evin sınırları da bulanıklaşmaya başlamıştır. Bugün evler, biçimsel örgütlerin taşıdıkları bazı özelliklere sahip kılınmak yoluyla, birer mini-örgüte dönüştürülebilmektedir.

Bir ev, bir yaşam biçimini (veya bir hanehalkı kültürünü) tanımlayan bir varlık olarak görülebilir (Avery ve Baker, 2002). İşte bu ev/hanehalkı, kendine bazı işletme vasıfları ekleyerek, kendi üyelerinin faydalarının maksimize etmeye çalışması beklenen bir varlığa dönüştürülebilmektedir. BT'nin gelişmesiyle böyle bir dönüşüme ilişkin nesnel imkânlar artmıştır. 
BT'nin, engellilerin ve evlerinden pek çıkamayan (örneğin çocuk ya da yaşlı kişilere bakmakla yükümlü olan) kişilerin çalışma isteklerini gerçekleştirebilecekleri bir ortam yaratma özelliği vardır (Miller ve Cardy, 2000). BT yoğun çalışma düzeni, iş ortamı ile ev ortamında meydana gelen sorunlardan birinin diğer ortama taşınma sıkıntısını da ortadan kaldırabilir.

Diğer taraftan bireyler, aynı mekândaki rol değişimlerini birbirleriyle gerçekleştirmeyi başaramıyabilirler. Ayrıca evde isdihdam, çalışanların ücret ve çalışma koşulları gibi haklarının alınmasına engelleyici bir tehdit oluşturabilir (Bensghir, 1996).

Evde isdihdam, çeşitli etik tartışmalara da konu olmaktadır. Elektrik, ısınma gibi işveren evinin özel kaynaklarının çalışanlar aracılığıyla kullanılması, çalışanın evdeki işinde fazla mesai yapması durumundaki haklarının alınması gibi konular, sorun oluşturabilmektedir. Bundan başka, ev halkının iş ve ev dengesini sürdürebilmesi veya sürdürememesi de başlıbaşına bir sorundur.

\section{İnsan Kaynakları Yönetimi Uygulama Biçimlerini Etkileyen Değişimler} Insan Kaynakları Bilgi Sistemi (IKBS)

İnsan Kaynakları Bilgi Sistemi (IKBS), insan kaynakları yönetiminin destekleyici bir unsurudur ve dolayısıyla aşağıda boyutları belirlenecek olan farklı bir işleve işaret eder. İKBS, bir örgütteki insan kaynaklarına dair bilginin toplanması, depolanması ve analiz edilmesi için kullanılan bütünleşik bir sistemdir (Hendrickson, 2003; Legnich-Hall ve Moritz, 2003).

IKBS, yalnızca bir yazılım ve donanımdan oluşmaz; aynı zamanda insanları, politikaları, süreçleri ve insan kaynakları işlevlerinin yerine getirilebilmesi için gerekli tüm bilgileri içerisinde barındırır. Dolayısıyla sistemin, insan kaynakları profesyonelleri, işlevsel alandaki yöneticiler ve hatta çalışanların kendileri olmak üzere birçok kullanıcısı vardır.

IKBS, kaynakları artırmaksızın yapılabilen işlemleri artırdığı için verimliliği; doğruluk, tamlık özellikleri nedeniyle ve süreçleri basitleştirdiği için de etkililiği artırabilir. Ayrıca IKBS, "çevrimiçi" (on-line) veya bilgisayar temelli uygulamalar çerçevesinde BT'nin yoğun kullanımına olanak tanımaktadır.

İnsan kaynakları yönetimi, tüm örgütü içeren yapısından ötürü, bilgi yönetim sistemlerinin kurulmasında ve sürdürülmesinde bir imkân sağlayıcıdır. Bu bağlamda, bazı yönetim bilgi sistemleri, IKKBS'yi de içine alan ve örgüt bütünü çapında işlevselliği bulunan bir sistem olarak uygulanabilir. Örneğin, işletmenin işlevlerini ortak veri tabanlı tek bir sistem bağlamında bütünleştirmekte olan ve kurum veya firma çapında bir paket olarak tanımlanan "Kurum Kaynak Planlama Sistemleri-KKPS" bu biçimde bir sistem yaklaşımı sunmaktadır (Newell, Huang, Galliers ve Pan, 2003). 
BT'nin insan kaynakları yönetiminin hemen her uygulamasına yansıyan değişimleri olmakla birlikte, aşağıda sözü edilen etkileşimler, (çalışmanın sınırlııkları uyarınca) en temel insan kaynakları işlevlerine özgü bağlamlar çerçevesinde ele alınacaktır.

\section{Personel Sağlama ve Seçme}

BT'de meydana gelen değişmelerin, işe eleman alma süreçlerine yansımaları da vardır. Örneğin, grup destek sistemleri, işe eleman seçme sürecinde bir mülakatı birden fazla mülakatçının farklı mekanlardan yürütmesine imkan sağlayan bir yazılım ve donanım bütünü olarak algılanabilir (Tullar ve Kaiser, 1999). Bu şekilde yürütülen bir mülakat, zaman, mekan, uzaklık kısıtlarını ortadan kaldırdığı için maliyetler yönünden de avantajıdır. Öte yandan, özellikle uluslararası insan kaynakları seçme süreci düşünülürse, herhangi bir bölgede bulunan uzmanlara sürece katılma şansı tanıyabilmenin önemi daha iyi anlaşılır. Diğer taraftan, gerçi bilgiyi ölçmeye yönelik mülakatlarda böylesine bir sistemin üstünlükleri vardır; ancak bu üstünlüklerin sosyal etkileşimi zayıflatıp zayıflatmayacağı da bir sorun olarak ortaya çıkmaktadır.

Aslında, BT vasıtasıyla personel sağlama ve seçme yapılmasının birçok faydaları vardır. Bunların en önemlileri, daha fazla adaya ulaşabilme, özel bir aday kitlesini hedeflemenin daha kolay oluşu, iş tayin etme maliyetinin göreceli olarak düşüklügü, seçmenin hızlı yapılabilmesi, aracıların mevcut olmayışı, daha iyi özgeçmiş yönetiminin sağlanması, daha az bürokratik işlem, sonuçta genellikle daha isabetli seçim yapmış olmaktır (Singh ve Finn, 2003).

Personel seçiminde kişi-iş uyumunun varlığını daha iyi saptayabilmek amacıyla (bilimsel ve objektif bir değerlendirme yöntemi olarak) psikoteknik ölçüm ve değerlendirme yöntemleri kullanılmaktadır. Psikoteknik testlerle adaylardan standart, sistematik ve objektif bilgi sağlanması hedeflenmektedir. Psikoteknik ölçümle yapılmak istenen ise, esas itibariyle adayların zekâ yapısı, yetenekleri, kişilik özellikleri, bilgi düzeyleri ve yaratıcılıklarının analiz edilmesi, bu özelliklerin kümelenmesi ve toplanan bulguların, gerektiğinde hem kişilerarası karşılaştırmalar yapmak üzere, hem de kişilerin gelecekteki davranışlarını yönlendirmek üzere kullanılmasıdır (Erdoğan, 1997). Görüleceği üzere, psikoteknik ölçüm ve değerlendirme yöntemleri de, veri toplama ve analizi aşamalarında BT'nin yoğun bir biçimde kullanıldığı bir davranışsal teknikler bütününden oluşmaktadır. 


\section{Eğitim ve Geliştirme}

BT'nin öğrenilmesi gereken birçok şeyi beraberinde getirdiği açıktır. Ancak bazı işlerin ya da görevlerin, eğer ilgili profesyonel eğitim zamanında ve uygun yoğunlukta alınmamışsa, sonradan sunulan eğitim veya beceri geliştirme yollarıyla öğrenilmesi de her zaman mümkün olmayabilir (Singh ve Finn, 2003).

Yöneticiler, personel örgüt uyumunu "web" yoluyla sağlama ve seçme süreçlerinde, "web"-sayfasında hazır bulunan ve kişilikle ilgili birkaç soruyu içeren testle, adayı ön taramadan geçirmek suretiyle nispeten etkin bir değerlendirme sürecini başlatabilirler. Bunun gibi birçok yordamla, adayların BT aracılığıyla değerlendirilmesi süreci, çok kısa sürede ve etkin bir biçimde gerçekleştirilebilmektedir. Aynı bağlamda, işletmelere bırakılan binlerce özgeçmişi belli bir kıstasa göre yalnızca birkaç saniye içerisinde tarayabilmek mümkündür. Bu çerçevede, elektronik veri tabanlarında bulunan özgeçmiş formları da, çoğunlukla gereksiz bilgilerin toplanmasını önleyecek biçimde standartlaştırılmış olarak sunulmaktadır.

İnsan kaynakları yönetiminde, sosyal etkileşimin yüksek olduğu bazı faaliyetlerde bile ileri teknolojilerinden önemli ölçüde yararlanılmaktadır. Bu bakımdan eğitim ve geliştirme faaliyetlerinde ileri teknolojinin kullanılmasının sağlayacağı avantajların başında, eğitimin verileceği mekânla ilgili kısıtlamaların kalkmış olması gösterilebilir. Şüphesiz ki, aynı çerçevede eğitimin temelindeki zaman faktörü de bir diğer değişken olarak ele alınmalıdır (Baird, Griffin ve Henderson, 2003) ve bu açıdan da BT kullanımının sağlayabileceği önemli eğitim hızı artışları söz konusudur.

Bu noktada unutulmamalıdır ki, BT zaman ve mekan açısından yeni seçenekler sağlasa da, klasik öğrenme yöntemlerinin örgütteki diğer kişilerle birlikte performans gelişimini mümkün kılan "bilgiyi paylaşma fırsatları" daha önemli olabilir. Dolayısıyla, klasik veya yüksek BT kullanımlı yöntemlerden birini seçerken, kişisel ve yapılan iş açısından en iyi sonuçları sağlayan yöntemi seçmek esas olmalıdır. Aslında, sonuçta düşünülebilecek en iyi yöntem, bir karma yaklaşım da olabilir.

\section{Performans Değerlendirme}

Performans değerlendirme, personelin kendisinden beklenen görevleri ne derecede iyi gerçekleştirdiğini belirlemeye yönelik bir süreçtir. Öte yandan, bir performans değerlendirme sürecinin başarıya ulaşabilmesindeki en önemli etkinin, çalışanın kendi performans değerlendirme sürecinden duyduğu tatmin olduğu söylenebilir.

Yöneticilerin, performans değerlendirme süreçlerinin tasarlanması ve 
uygulanması aşamalarında, kullanmaya eğilimli oldukları performans değerlendirme sisteminin "adil" yapılandırılmış olup olmadığına veya çalışanlar üzerinde bir "adil değerlendirme" algısının bu sistemle yaratılabilmiş olup olmadığına dikkat etmeleri gerekir. Bu önemlidir, çünkü performans değerlendirmenin yoğun öznel niteliği nedeniyle, değerlendirenin sahip olduğu birçok yargı, tutum, düşünce ve duyguyu değerlendirme sürecine dahil etme riski daima vardır. BT, hem performans değerlendirmesini kolaylaştırmada, hem de bahsedilen bu algının oluşturulmasında bazı olumlu etkiler yaratabilir. BT, sözü edilen adalet duygusunu verebilecek bir performans ölçümü sağlayabilir. O kadar ki, BT yoluyla ölçüm, performans geribildirimi ile çalışanları işyerinde tutma, güdüleme ve geliştirme bakımından ayrı bir teşvik bile sağlayabilir.

Söz konusu bağlamda BT'nin, özellikle (üretim miktarı, süre hata sayısı v.b. gibi) çıktılara dönük, yani denetleme ve izleme amaçlı performans değerlendirmeyi destekleyen bir özelliği bulunabileceğini akılda tutmak gerekir. BT, performans değerlendirme sürecinde bilgisayarla performansın takip edilmesi şeklinde ve sonra performans raporlarının ve geribildirimlerinin oluşturulması sürecinde devreye girebilir (Miller, 2003).

Diğer taraftan, yüz yüze iletişimin bulunmadığı tele-iletişim ortamlarında kişilerarasındaki güven duyguları daha zayıf olabileceğinden, bazı durumlarda bilgisayarlı takip, güven sarsıcı olabilir; çalışanlara, değerlendirmenin asıl işlevinin yalnızca kontrol olduğunu düşündürtebilir. Bununla birlikte performans değerlendirme işlemi temelde çalışanın üzerinde yönetim baskısının artığı hissini uyandırdığı için, performans geribildiriminin amirce değil de bilgisayarca yapılması, çalışanlarca daha fazla tercih edilen bir yaklaşım olarak düșünülebilir.

Öte yandan, bütünüyle BT'ye dayandırılmış bir performans değerlendirmesini uygulayabilmek de oldukça zordur. Rutin veya tekrarlayan işlere nazaran, eğer performans ölçümleri yaratıcılık, iletişim, problem çözme yeteneği gibi boyutları da kapsamak durumundaysa, bu ölçümlere yönelik olarak BT'nin kullanılması zorlaşacaktır.

Psikoteknik ölçümlerde BT'nin nasıl kullanıldığına yukarıda değinilmiştir. Bu bağlamda BT'ye dayalı ölçümler, dışsal nedenlerden veya beklenmedik karmaşık etmenlerden kaynaklanan ve bu yüzden de kimi zaman testin normal süresini aşarak değerlendirilecek sürecin tamamlanmamasına neden olan durumlara saplanıp kalmaktan kurtulmayı sağlayabilir. Buna karşın, BT kullanımı ile yapılacak değerlendirmelerde işin çoğunlukla sadece ölçülebilir yanlarının yer alabildiği ve bunun da her zaman yeterli bir değerlendirme kazandırmayabileceği de unutulmamalıdır.

Teknoloji-yoğun sektörlerdeki işletmeler, BT yoğun performans 
değerlendirme tekniklerini daha kolay benimseyebilmektedirler (Miller, 2003). Bu tür yöntemler, işletmelere yılda birden fazla değerlendirme yapabilme kolaylığı da sağlamaktadırlar.

\section{Ücretlendirme}

Tele-iletişim ve onun yarattığı tele-iş ve evde isdihdam, bu tür çalışanların ücretlerini saptamayı oldukça karmaşık bir hale getirmiştir (Bensghir, 1996). Bu gibi durumlar, insan kaynakları yöneticilerini işin niteliği (iş tanımı), o işi yapacak personelde olması gereken nitelikler (iş gerekleri) konularında ayrıntılı çalışmalar yapmaya yöneltmektedir. Kısacası, iş analizi BT'ye odaklanmış bir süreç haline dönüşmektedir.

BT'nin kullanımı ile ilgili olarak yüksek becerili işilere olan intiyacın gerçekte var olan intiyaca kıyasla abartılı olması, diğer bir deyişle "beceri önyargıı" olma, sonuçta BT ile ilgili işlerde çalışanların (dünya ölçeği esas alındığında) diğerlerine nazaran daha yüksek ücret almalarına neden olmaktadır (Entorf ve diğerleri, 1999; Borghans ve Weel, 2004). Kısaca, BT'nin varlığı, becerili işgücü talebinin ve bu açıdan artan ücret eşitsizliğinin bir kaynağı olmaktadır. Üstelik, teknoloji-yoğun olmayan işletmelerde bu fark, daha büyüktür (Goss ve Philips, 2002). Çünkü teknoloji-yoğun işletmelerde çalışanların BT'ye hakim olmaları, üstünlük yaratacak bir farktan ziyade, bir zorunluluktan başka bir şey değildir.

\section{Sonuç}

Bu çalışmada BT'nin yarattığı ve insan kaynakları politika ve uygulamalarına yansıyan değişimler, Şekil 1'de özetlenmektedir. Şekille anlatımda, Miller ve Cardy'nin (2000) çalışmasından esinlenilmiştir.

\section{Şekil 1. İnsan Kaynakları ve Teknolojinin Açık Sistem Modeli ÖRGÜT Teknoloji Sistemi}

\begin{tabular}{|c|c|c|}
\hline $\begin{array}{l}\text { IKY ÖNCESI } \\
\text { (Politika Belirlemede Etkili Konular) } \\
\text {-Ademi merkeziyetçileşme } \\
\text {-Yeni istihdam iliskileri } \\
\text {-Ortak çalışma biçimlerinde değişmeler } \\
\text { - Tele-iletişim } \\
\text {-Eğitim ve beceri gereksinimien } \\
\text {-Aracıların azalması } \\
\text {-Evörgütler }\end{array}$ & $\begin{array}{l}\text { IKY ARA ÇIKTILARI } \\
\text {-IKBS } \\
\text {-Personel Sağlama Seçme } \\
\text {-Eğitim ve Geliştirme } \\
\text {-Ucretlendirme } \\
\text {-Performans Deg̉erlendirme }\end{array}$ & $\begin{array}{l}\text { CYALIŞAN AÇISINDAN } \\
\text { IKYY SONUÇLARI } \\
\text {-Beceri nitelikleri } \\
\text {-Tatmin } \\
\text { - Kariyer } \\
\text {-Aile }\end{array}$ \\
\hline
\end{tabular}


BT çerçevesinden bakıldığında ortaya çıkan ve insan kaynakları yönetimi uygulamalarına da yansıyan değişimler, çalışan açısından başta beceri niteliklerini, iş tatminini ve ayrıca onun kariyerini, ailesini de ilgilendiren çeşitli sonuçlar doğurmaktadır.

İnsan kaynakları yönetimi çerçevesinden bakıldığında ise, BT'nin, verimliliği artırırken aynı zamanda insanların izolasyonuna da sebep olduğunu ve bu nedenle çalışanın otomatikleşmiş (şahsi olmayan) bir iş çevresine düşmesine ve dolayısıyla iş tatmininin azalmasına yol açabilmektedir. Diğer taraftan, BTyoğun ortamın, artmış moral, daha iyi kararlar ve daha az süreç kayıpları nedeniyle daha esnek çalışma düzenlemeleri yapılabilmesi sonucunda, çalışanlar üzerinde olumlu etkiler yaratmaktadır (Miller ve Cardy, 2000).

Her iki bakış açısının da haklı tarafları olmakla birlikte, BT-yoğun iş ortamlarında, geleneksel iş yapma yöntemlerinin bulunduğu örgütlerden farklı olarak, politika belirleme ve uygulama süreçlerini saptarken, BT'nin insan üzerindeki etkilerine daha dikkatli bir biçimde odaklanmalıdır. Bu bağlamda, karşılıklı bağlılık ve geniş çaplı olarak paylaşılan değerlerdeki uyuşum, BT’li yaklaşımlar için daha uygun bir ortam yaratacaktır.

\section{Örnek Olay}

Gerçek bir durumsallığın literatürle uyuşan ya da uyuşmayan yanlarının neler olabileceğine dair en azından bazı ipuçları elde edebilmek amacıyla, bu çalışmanın sonuna, aşağıda anlatımı yer alan örnek olay incelemesi gerçekleştirilmiştir. Örnek olay incelemesinde söz konusu işletmenin insan kaynakları müdürü ile derinlemesine yapılan yarı-yapılandırılmış bir mülakat ve ayrıca işletmenin internet sitesinden alınan bilgiler kullanılmıştır. Anlatımda, işletmenin gerçek adı yerine Teknoloji A.Ş. (TAŞ) takma adı verilmiştir.

\section{Şirketin Genel Durumu}

TAŞ, Türkiye'nin haberleşmede elektro-mekanik sistemlerden elektronik sistemlere geçişinde öncülük yapmış bulunan telekomünikasyon firmalarından biridir. TAŞ'ın 29 yönetici, 280 teknisyen, çoğu ArGe'de çalışan ve 71'i mühendis olmak üzere toplam 445 çalışanı bulunmaktadır. TAŞ’ın ürün yelpazesi, çeşitli kapasitelerde elektronik telefon santrallerini ve bu santrallerle birlikte kullanılabilen özel telefon setlerini, sesli yanıt sistemlerini, bilgisayar ve telsiz haberleşme arabirimlerini içermektedir. TAŞ, satış cirosunun \%10'unu araştırma-geliştirme yatırımlarına ayırmaktadır. İşletmenin herhangi bir lisans veya "yöntem bilgisi" (know-how) bağımlıı̆ı yoktur. İşletme, operasyonel ve yönetsel faaliyetlerini matriks örgütlenme yapısı ile üç farklı şehre dağıtmıştır. İnsan kaynakları birimi, üretim ve ArGe aynı şehirde bulunmaktadır. 
Ortak Çalışma Biçimlerinde Değişmeler (Örgütsel Illetişim)

Insanların bilgisayarların başında durmaları ise, iletişimle ve sosyal etkileşimle ilgili bazı sorunların yaşanmasına yol açmaktadır. Son iş memnuniyeti çalışmasında "birimlerarası iletişim yokluğu", en fazla rahatsız olunan konu olarak belirlenmiştir. Insan kaynakları müdürü, bu durumu şu şekilde ifade etmektedir: "... Bilgisayarın başında oturan kişi bilgiye çok kolay erişmekte, ancak o bilgiyi oraya kim giriyor, nasıl giriyor, onu oraya ne gibi şartlarda koydu, hiçbir fikri yok. Yani empati kuramıyor. Oysa bilmeli, herhangi bir sorunla karşılaşı̆̆ı̆ında karşı taraf bunu neden yaptı, ya da yapmadı; bunu anlaması gerek. Ya da karşı tarafın talep ettiği bilginin neden acil olduğu hakkında fikri yok; sonuçta kendi dünyasında yaşıyor. Kendi bakış açısı ve doğrularıyla yaklaşıyor...Çalışanlar başka bir bölüm ya da odaya gitmedikleri için, sosyal ortamdan uzaklaşmaya başlıyorlar. Kimi zaman bir kişi, iki ofis ötesinde birkaç yıl çalışıp ayrılmış bir başka kişinin varlığından bile haberdar olmayabiliyor..."

İşletmede, bilgi teknolojilerinin gelişimi neticesinde bazı görevlerin yok olması gündeme gelmekle birlikte, bir "iş" hiçbir zaman tümüyle yok olmamaktadır. Bahsedilen durumun bir örneği, işletmenin KKPS'ye geçiş aşamalarında yaşanmıştır.

KKPS yoluyla tüm çalışanlar, birimlerin veri tabanlarına kolaylıkla ulaşabilme şansına sahiptirler. Çalışanlar, önceleri kayıt altına almadıkları çok çeşitli bilgiyi artık her zaman bilgisayara girmek zorundadırlar. Ancak, daha önce kağıtlar ve dosyalar dolusu bilgiye dayanarak oluşturulan raporların içerdikleri bilgiler, artık kişilerin önlerindeki bilgiasayarlarda hazır bir şekilde bulunmaktadır. Özellikle bilgiye erişim anlamında işlerin, her geçen gün biraz daha hız kazanıp kolaylaşıı̆ı görülmektedir. Daha önce aynı işleri (örneğin bütçe hazırlamayı) yapan kişiler, artık verileri analiz etmek, yorumlamak, onlardan sonuçlar çıkarmak ve eskiye göre daha fazla boyutu bulunan raporlar hazırlamak zorunda kalmışlardır. Bununla birlikte, KKPS'ye geçiş, bir takım sorunların yaşanmasına da neden olmaktadır. Bu açıdan, bazı çalışanların alışkanlıklarından kolaylıkla vazgeçemedikleri görülmektedir. Sözgelimi, üretim kademesine hangi verinin gideceği veya kime hangi raporun gönderileceği konularında sorunlar yaşanabilmektedir.

\section{Tele-iletişim}

Kurum içi iletişimde ve evrak bilgi akışında, e-posta oldukça yoğun bir biçimde kullanılmaktadır. Sözgelimi sağlık sigortası gibi herhangi bir konuda bilgi verileceği zaman, çalışanlar, kullanıcı kodlarıyla işletmenin intra-net sayfasından bu bilgilere ulaşabilmektedirler. İşletme kurum kaynak planlama sistemlerini (KKPS) kullanmaktadır. Ancak, sistemin tam olarak yerleşmesi ve 
benimsenmesi süreci halen devam etmektedir.

\section{Eğitim ve Beceri Gereksinimleri}

Personelden gelişimi yakalayamayan ya da kendini gelişmeye uyarlamayı başaramayan çalışanların, başlangıçta, içsel olarak kaldıramayacakları sıkıntı ve zorluklarla karşılaştıkları söylenmektedir. Ayrıca, bu kişilerin, başarılı olanların aldıkları (terfi, ücret artışı v.s. gibi) karşılıkları alamıyor olmaları, onların, bir müddet sonra kendi istekleriyle sistem dışında kalmalarına sebep olmaktadır. Bir bakıma sistem, bu adaptasyonu gerekli kılmaktadır.

İş süreçleri ise, iş akışına göre değil, kişilere dayalı olarak yürütülmektedir. Yani herhangi bir işin nasıl yapılacağı düşünüldügünde, genellikle kurallar veya prosedürler değil, kişi isimleri akla gelmektedir. Son zamanlarda, insan kaynakları yönetimi, anlatılan bu durumu değiştirmek üzere, sistemi daha biçimselleştirmeye yönelik bir takım çalışmalar yapmaktadır.

\section{Aracıların Azalması}

TAŞ'da literatürde belirtildiğinden farklı olarak ortaya çıkan en önemli konu ise, örgütsel kademe sayısındaki artıştır. İnsan kaynakları birimi, iş değerlemesini kolaylaştırması ve işletmenin farklı yerlerdeki bölümleri arasında uyum sağlanabilmesi için kademelerin sayısını azaltma çalışması yapmış, ancak operasyonel kısımda bu başarılabilse bile, ArGe'de başarılamamıştır. Bir kısım çalışanın ve özellikle mühendislerin yüksek bir donanımla bu işe girdikleri ve geldikleri andan itibaren birçok şey öğrenip kendilerini geliştirdikleri; sonuçta fark yaratacak bir terfi, ödül ve her şeyden önce de bir unvan beklentisi içine girdikleri anlaşılmaktadır. Dolayısıyla onların istekleri, zaman içerisinde kademelerin sayısını artıran bir etki yaratmaya başlamıştır.

\section{Ev Örgütler}

TAŞ'da, birlikte çalışmayı gerektiren operasyonel düzeylerin dışındaki işlerde esnek çalışma saatleri uygulaması vardır. Çalışanın aylık toplam çalışma saatleri içinde işletmede bulunması beklenmekle birlikte, mesaiye ne zaman gelip ne zaman gideceğine ilişkin sorumluluk, birim yöneticilerine verilmiştir. İnsan kaynakları müdürü, bu durumu şu şekilde dile getirmektedir: “...Çalışan eline alır disketini, "laptop"ını, gider evine; gerekirse de "network"e bağlanır. Ben ona derim ki: 'Şu iş Cuma'ya kadar şu aşamaya gelecek!' Onun bunu nerede, nasıl yapacağı, onu ilgilendirir. Zaten işler bu biçimde yapılmaya başlandıkça, birimler de işleri parçalara ayırmaya başlıyor. Parçalara ayırıp, ilgili kişilere dağıtıyorlar..." 
Insan Kaynakları Yönetimi Uygulamaları Açısından TAŞ’ın Durumu

TAŞ, insan kaynakları uygulamaları bakımından, Vestel, Arçelik, Aselsan gibi elektronik sektöründe faaliyet gösteren firmaların genel özelliklerini taşıyan yapıları gibi insan kaynakları biriminin (kadrolama, performans değerlendirme, eğitim v.s. gibi) tüm işlevlerine yansıyan en önemli odaklaşma alanları, "üretim ve BT"dir.

Firmanın insan kaynakları gruplaması ise, üretimciler, ArGe'ciler ve satış̧ılar olarak üç ana grupta toplanabilecek personel açısından bazı farklılaşmalar göstermektedir. Tüm ArGe çalışanları, sürekli olarak kendilerini geliştirmek ve okumak zorundadırlar.

\section{IKBS}

TAŞ, ISO 9001 belgesine sahip olmakla birlikte, ofis grubunda (idari işlerde) çalışanlar bilinen anlamda dosya tutmamakta, onun yerine (prosedürler de dahil olmak üzere) işlerini bilgisayar ortamında sürdürmekte ve muhafaza etmektedirler. ArGe'dekiler ise, tüm yazılımlarını, bütün kart tasarımlarını bilgisayarlarda hazırlayarak, onları yine bilgisayar ortamında test etmektedirler. Bilgisayar kullanıcısı olmak, çalışanlar arasında herhangi bir fark yaratmamaktadır; çünkü işe girişte herkesin en azından ofis programlarını bilmeleri şart koşulmaktadır.

\section{Personel Sağlama ve Seçme}

işe eleman alma sürecinde, aday havuzunun $1 / 5^{\prime}$ i işletmenin internet sayfasına, $1 / 5$ 'i stajyerlerin doğrudan doğruya işletmeye, ve $3 / 5$ 'i de internet üzerinden hizmet veren danışmanlık firmalarına yapılan başvurulardan oluşmaktadır. Bu adaylardan, daha önce orada çalışmış bulunan stajyerler işe daha fazla oranda kabul edilmektedirler. Buna karşın, ArGe düzeyindeki alımlarda ise, internet'teki danışmanlık firmalarına yapılan başvurular ağırlık kazanmaktadır.

Teknisyenlerin toplu alımlarında, teknik içerikli standart soruların yöneltildiği mülakatlar yapılmaktadır. Bireysel mülakatlar ise daha az yapılandırılmış bir niteliğe sahiptir. İşe alım süreçlerinde psikoteknik testler ya da kişilik testleri uygulamaları, her işin gerektirdiği kişilik özelliklerini tespit etmenin zorluklarından ötürü tercih edilmemektedir.

\section{Eğitim ve Geliştirme}

Eğitim ve geliştirme faaliyetleri, her yıl insan kaynakları yönetimi biriminin belirlediği bir ana konuda düzenlenmektedir. Örneğin, önceki yılın konusu, orta kademeli yöneticilerin eğitimi olarak belirlenmişti. Bundan başka eğitim, 
bölümlerinden gelen ihtiyaç ve istekler doğrultusunda da düzenlenebilmektedir.

\section{Performans Değerlendirme}

Yakın zamanda, bir yazılım firmasının TAŞ için hazırladığı performans değerlendirme programına geçilmesi planlanmaktadır. Şu andaki performans değerlendirmesi, amir ve astın karşılıklı olarak birbirlerini değerlendirmesi şeklinde sürdürülmektedir. İnsan kaynakları birimi, öngörülen yeni uygulamayla, daha fazla değerlendiricinin bulunacağı, veri toplama ve analiz süreçlerinin daha hızı yürütüleceği, kullanımı kolay elektronik bir sistem kurmayı hedeflemektedir. Öte yandan, KKPS'den çıktıya dayalı performans değerlendirme sistemine girdi sağlayabilecek türden (üretim sayısı, hata sayısı v.s. gibi) bilgilerin elde edilmesi amaçlanmamaktadır.

\section{Ücretlendirme}

Çalışanlar arasında, aldıkları ücretler açısından en önemli farklar, BT becerilerindeki artışlardan ziyade, yönetsel görevlerdeki kademelerde ortaya çıkmaya başlamaktadır. Bu ise, BT-yoğun sektörler için beklenen bir durumdur.

\section{Genel Değerlendirme}

Örnek olayın incelenmesi sonucunda literatürün, gözlenilen iş hayatındaki birçok duruma değindiği görülmektedir. TAŞ'da performans değerlendirme uygulamalarında BT'nin daha fazla kullanılmasına ilişkin çabalar gösterilmekle birlikte, BT'nin tespit ettiği çıktılara dayanmanın tercih edilmediği görülmektedir. Bunun yerine, özünde geleneksel olan ve değerlendirmeyi kişilerin yaptığı sistemlerin tercih edildiği söylenebilir. İşe eleman alma süreçlerinde ise, çok boyutlu kişilik özelliklerini sorgulamak yerine, daha çok işe dönük değerlendirme süreçlerine yönelmektedirler.

İnsanların bilgisayarları başındayken gittikçe izole oldukları ve sosyal etkileşim açısından sorunlar yaşayabilecekleri savı, TAŞ'da da geçerliliğini korumaktadır. Hiyerarşik kademelerin sayısındaki "azaltılamama" durumu ise, uygun yapıya rağmen "insan"ın, yani "içeridekiler"in etkisini apaçık ortaya koymaktadır.

Dikkat çekilmesi gereken bir diğer konu ise, TAŞ’ın "kendi en iyi uygulamalar karması"nı yaratma çaba ve kararlılığıdır. Bu durum ise, benzer ortamlar için geçerli olabilecek reçete nitelikli yönetsel çözümlerin, buradaki uygulanma imkânsızlığının bir sonucudur. 


\section{Kaynakça}

Alkadi, I., Alkadi, G. ve Totaro, M. (2003). Effects of information technology on the business. World Human Systems Management, 22 (3), 99-103.

Autor, D.H., Levy, F. ve Murnane, R.J. (2003). The skill content of recent technological change: An empirical. exploration. Quarterly Journal of Economics, 118 (4), 1279-1333.

Avery, G.C. ve Baker, E. (2002). Reframing the infomated household-workplace. Information and Organization, 112, 109-34

Baird, L., Griffin, D. ve Henderson J. (2003). Time and space: Reframing the training and development agenda. Human Resource Management, 42 (1), 39-52.

Bensghir, T.K. (1996). Bilgi teknolojileri ve örgütsel değişim. Ankara : TODiE.

Borghans, L. ve Weel, B. (2004). What happens when agent T gets a computer? The labor market impact of cost efficient computer. Adoption Journal of Economic Behavior and Organization, 54, 137-151.

Bresnahan, T.F., Brynjolfsson, E. ve Hitt, L.M. (2002). Information technology, workplace organization, and the demand for skilled labor: Firm-level evidence. Quarterly Journal of Economics, 117 (1), 339-376.

Chan, S.L. (2000). Information technology in business processes. Business Process Management, 6 (3), 224-237.

DeMarie, S.M. ve Hitt, M.A. (2000). Strategic implications of the information age. Journal of Labor Research, 11 (3), 419-429.

Entorf, H., Gollac, M. ve Kramarz, F. (1999). New technologies, wages, and worker selection. Journal of Labor Economics, 17 (31), 464- 491.

Erdoğan, ì. (1997). Işletmelerde kişi değerlemede psikoteknik (7. bs.). İstanbul: i..Ü. İşletme Fakültesi.

Goss, E.P. ve Phillips, J.M. (2002). How information technology affects wages: Evidence using internet usage as a proxy for IT skills. Journal of Labor Research, 23 (3), 463-474.

Hendrickson, A.R. (2003). Human resource information systems: Backbone technology of contemporary human resources. Journal of Labor Research, 24 (3), 381- 394.

Hitt, M.A., Keats, B.W. ve DeMarie, S.M. (1998). Navigating in the new competitive landscape: Building strategic flexibility and competitive advantage in the 21st century. Academy of Management Executive, 12, 22-42. 
Legnick-Hall, M.L. ve Moritz S. (2003). The impact of e-HR on the human resource management function effects of infonnation technology on recruitment. Journal of Labor Research, 24 (3), 365-379.

Maruca, R.F.(1998). How do you manage an off-site team? Harvard Business Review, 76, (July-August), 22-26.

Miller, J.S. (2003). High tech and high performance: Managing appraisal in the information age. Journal of Labor Research, 24 (3), 409-424.

Miller, J.S. ve Cardy, R.L. (2000). Technology and managing people: Keeping the, "Human" in human resources. Journal of Labor Research, 11 (3), 447- 461.

Newell, S., Huang, J.C., Galliers, R.D. ve Pan, S.L. (2003). Implementing enterprise resource planning and knowledge management systems in tandem: Fostering efficiency and innovation complementary. Information and Organization, 13, 25-52.

Scott, W.R. (1998). Organizations: Rational, natural and open systems. New Jersey: Prentice Hall, Inc.

Singh, P. ve Finn, D. (2003). The effects of information technology on recruitment. Journal of Labor Research, 24 (3), 395-408.

Townsend, A.M. ve Bennett, J.T. (2003). Privacy, technology and conflict: Emerging issues and action in workplace privacy. Journal of Labor Research, 24 (2), 195-206.

Tullar, W.L. ve Kaiser P.R. (1999). Using new technology: The group support system. R.W. Eder ve M.M. Harris (Yay. Haz.). The Employment Interview Handbook içinde, (ss. 279-292). California: Sage Publications.

Turban, E., McLean, E. ve Wetherbe, J. (2002). Information technology for management (4th ed.). New York: John Willey and Sons, Inc.

Wimmer, B.S., Townsend, A.M. ve Brian, E.C. (2000). Information technologies and the middleman: The changing role of information intermediaries in information reach economy. Journal of Labor Research, 11 (3), 407-418. 